CASSOWARY volume I (1): 1 - 20

ISSN : 2614-8900

E-ISSN : 2622-6545

CProgram Pascasarjana Universitas Papua, https://pasca.unipa.ac.id/

\title{
Sanitasi Pantai dan Kualitas Perairan Pulau Mansinam pada Kondisi Arus Permukaan Monsun Timur
}

The beach sanitation and water quality of Mansinam Island in the surface flow condition in the East Monsoon

Jean Irene Wyzer*, Sri Hartini, Max J. Tokede

Program Studi Ilmu Lingkungan, Universitas Papua

Jalan Gunung Salju Amban, Manokwari, Kodepos 98314, Papua Barat, Indonesia

*Email: jwyzer@gmail.com

\begin{abstract}
Domestic waste caused by human activities in the bay area periodically can accumulate the coast of Mansinam Island and have a negative impact on sanitation and water quality. The direction of sea level currents in the East Monsoon (June-August) is generally moved from the West and come into the bay area. This study aims as follow: 1) To analyze the water quality (physical, biological, chemical and dissolved metals) on the coast of Mansinam Island based on the required quality standards for marine tourism activities; 2) To Analyze the level of coastal pollution on Mansinam Island based on the value of the Pollution Index (PI); 3) To identify the type and volume of pollutants in the coastal area of Mansinam Island in the East Monsoon. The PI indicates that at stations I, III and IV of the waters are lightly polluted, while the waters at the station II has been moderately polluted. The water quality parameter value of Station II has exceeded the quality standard for marine tourism in accordance with Kepmen. LH. No. 51 of 2004 consisting of TSS, nitrate, phosphate, oil and fat, total coliform and faecal coliform. In Station I, the water quality that exceeds the standard for nitrate, phosphate, and copper, while station III and station IV where higher on TSS value of nitrate, phosphate, oil and fat, and total coliform than the standard. Based on the results of the study, TSS values at station I to station IV were $56.67 \mathrm{mg} / \mathrm{L}, 196 \mathrm{mg} / \mathrm{L}, 116 \mathrm{mg} / \mathrm{L}$, and $157.33 \mathrm{mg} / \mathrm{L}$ respectively, while the fecal coliform value was $20 \mathrm{MPN} / 100 \mathrm{ml}$,> $2400 \mathrm{MPN} / 100 \mathrm{ml}$, 7.8 MPN/100 ml, and 11 MPN/100 ml. Nitrate and phosphate in Mansinam Island waters have an average value of $0.027 \mathrm{mg} / \mathrm{L}$ and $0.021 \mathrm{mg} / \mathrm{L}$. The physical, biological, chemical and dissolved metals of Mansinam Island marine waters in East Monsoon from 19 parameters observed by 12 parameters $(63 \%)$ are within the quality standard threshold and 7 parameters $(37 \%)$ have been above the standard quality threshold for Marine tourism. Pollution levels based on the Pollution Index of Mansinam Island's marine waters are mildly polluted for marine tourism purposes. The composition and density of waste types are found to be different in conditions of ebb and tide because the seasons in Indonesia are under the influence of monsoons, where the wind determines the occurrence of waves and surface currents in the waters on the bay areas.
\end{abstract}

Keywords: Beach Sanitation, Water Quality, Pollution Index, East Monsoon, Mansinam Island 


\begin{abstract}
ABSTRAK: Sampah domestik yang disebabkan oleh aktivitas manusia di kawasan teluk secara periodik dapat terakumulasi di pesisir pantai Pulau Mansinam dan berdampak negatif terhadap sanitasi dan kualitas perairan. Arah arus permukaan laut pada Monsun Timur (Juni-Agustus) dominannya adalah dari arah barat dan masuk ke dalam teluk. Penelitian ini bertujuan untuk : 1) Menganalisa kualitas perairan (fisik, biologi, kimia dan logam terlarut) pantai Pulau Mansinam berdasarkan baku mutu yang disyaratkan untuk kegiatan wisata bahari; 2) Menganalisis tingkat pencemaran pesisir pantai di Pulau Mansinam berdasarkan nilai Indeks Pencemaran (IP); 3) Mengidentifikasi jenis dan volume bahan pencemar (sampah) yang ada di kawasan pesisir pantai Pulau Mansinam pada Monsun Timur. Hasil analisis data untuk Indeks Pencemaran menunjukkan bahwa pada stasiun I, III dan IV perairan lautnya tercemar ringan, sedangkan perairan laut pada stasiun II telah tercemar sedang. Stasiun II memiliki nilai parameter kualitas air yang telah melebihi ambang batas baku mutu untuk wisata bahari sesuai dengan Kepmen. LH. Nomor 51 tahun 2004 yang terdiri dari TSS, nitrat, fosfat, minyak dan lemak, total coliform dan faecal coliform. Stasiun I memiliki nilai parameter kualitas air yang melampaui baku mutu pada nitrat, fosfat, dan tembaga, sedangkan stasiun III dan stasiun IV pada nilai TSS nitrat, fosfat, minyak dan lemak, dan total coliform. Berdasarkan hasil penelitian, nilai TSS pada stasiun I sampai dengan stasiun IV berturut-turut adalah 56,67 $\mathrm{mg} / \mathrm{L}, 196 \mathrm{mg} / \mathrm{L}, 116 \mathrm{mg} / \mathrm{L}$, dan 157,33 mg/L, sedangkan nilai fecal coliform yaitu 20 MPN/100 ml, >2400 MPN/100 ml, 7,8 MPN/100 ml, dan $11 \mathrm{MPN} / 100 \mathrm{ml}$. Nitrat dan fosfat di perairan Pulau Mansinam memiliki nilai rata-rata 0,027 mg/L dan 0,021 mg/L. Kualitas fisik, biologi, kimia dan logam terlarut perairan laut Pulau Mansinam pada Monsun Timur dari 19 parameter yang di amati 12 parameter $(63 \%)$ berada dalam batas ambang baku mutu dan 7 parameter (37\%) telah berada di atas ambang batas baku mutu untuk wisata bahari. Tingkat pencemaran berdasarkan Indeks Pencemaran perairan laut Pulau Mansinam tergolong tercemar ringan untuk tujuan wisata bahari. Komposisi dan kepadatan jenis sampah dijumpai berbeda pada kondisi surut dan pasang dikarenakan musim di Indonesia berada dalam pengaruh angin muson, dimana angin sangat menentukan terjadinya gelombang dan arus permukaan perairan laut teluk.
\end{abstract}

Keywords: Sanitasi pantai, Kualitas Perairan, Indeks Pencemaran, Monsun Timur, Pulau Mansinam

\section{PENDAHULUAN}

Pulau Mansinam adalah salah satu pulau yang terletak di Teluk Doreri, di sebelah selatan kota Manokwari dengan luas wilayah 410,97 hektar (Patahuddin, 2010). Pulau Mansinam dikenal sebagai situs bersejarah masuknya injil pertama kali di Tanah Papua, oleh karena itu pemerintah menetapkan Pulau Mansinam sebagai salah satu daerah tujuan wisata dengan objek tujuan wisata religi dan situs sejarah peradaban rakyat Papua. Pulau Mansinam selain dikenal sebagai situs bersejarah juga dikenal sebagai daerah tujuan wisata pantai karena panorama pesisir pantainya yang indah. Sebagai daerah tujuan wisata, tentunya sanitasi pantai dan kualitas perairan pesisir di Pulau Mansinam perlu dipelihara. Kebersihan pesisir pantai di Pulau Mansinam sangat dipengaruhi oleh aktivitas yang ada di sekitarnya baik aktivitas di laut maupun di darat. Selain itu, sejalan dengan bertambahnya penduduk di kota Manokwari, maka daerah pesisir menerima dampak yang cukup besar dengan masuknya berbagai bahan pencemar atau 
sampah dengan jenis dan volume yang terus meningkat dari tahun ke tahun. Jenis sampah buangan seperti; kantung plastik, logam, kaca, jaring, kain maupun sampah organik dapat mengurangi keindahan dan membahayakan kesehatan (Elyazar dkk, 2007). Keberadaan limbah buangan juga dapat mengancam ekosistem perairan yang ada di Pulau Mansinam seperti ekosistem terumbu karang dan ekosistem padang lamun.

Sampah domestik yang disebabkan oleh aktivitas manusia di kawasan teluk secara periodik dapat terakumulasi di pesisir pantai Pulau Mansinam dan berdampak negatif terhadap sanitasi dan kualitas perairan. Hal ini dikhawatirkan dapat mengurangi standar baku mutu air laut di Pulau Mansinam sebagai tempat wisata pemandian. Sanitasi pesisir dan kualitas perairan di wilayah pantai Pulau Mansinam perlu dipelihara agar dapat memberikan sumbangsih bagi kesejahteraan sosial dan ekonomi, serta meningkatkan kualitas hidup masyarakat setempat. Perairan pantai Pulau Mansinam memiliki dinamika oseanografi yang spesifik. Arus yang dipengaruhi oleh pasang surut dan angin dapat membawa tumpukan sampah dari kota Manokwari ke wilayah pesisir pantai Pulau Mansinam. Sampai saat ini belum diketahui apakah pengaruh arus (Monsun Timur) memberikan dampak terhadap sanitasi (kebersihan) dan kualitas perairan di pesisir pantai Pulau Mansinam.

Tujuan dari penelitian ini adalah untuk Menganalisa kualitas perairan (fisik, biologi, kimia dan logam terlarut) pantai Pulau Mansinam berdasarkan baku mutu yang disyaratkan untuk kegiatan wisata bahari. Menganalisis tingkat pencemaran pesisir pantai di Pulau Mansinam berdasarkan nilai Indeks Pencemaran (IP). Mengidentifikasi jenis dan volume bahan pencemar (sampah) yang ada di kawasan pesisir pantai Pulau Mansinam pada Monsun
Timur.

Hasil dari penelitian ini diharapkan dapat memberikan manfaat berupa informasi informasi kepada masyarakat, para stakeholder, dan pemerintah daerah mengenai tingkat sanitasi pesisir dan kualitas perairan Pulau Mansinam pada Monsun Timur.

\section{MATERI DAN METODE}

\section{Waktu dan Tempat Penelitian}

Penelitian ini dilaksanakan di pesisir pantai Pulau Mansinam, Distrik Manokwari Timur, Kabupaten Manokwari, Provinsi Papua Barat. Pulau Mansinam secara geografis berada pada 0054'00.34'LS dan 134005'58.01'BT.

Penelitian berlangsung pada akhir Agustus - September 2016 dengan penelitian dilapangan selama 2 hari untuk mengumpulkan dan mensortir sampah organik dan anorganik dari kuadran-kuadran setiap stasiun dilanjutkan dengan pengolahan data kualitas air di Laboratorium Kimia, Fakultas Matematika dan Ilmu Pengetahuan Alam (MIPA), Universitas Papua selama 3 minggu.

\section{Alat dan Bahan}

Alat dan bahan yang digunakan dalam pengambilan data dilapangan terdiri dari Hand GPS, sechi disk, termometer, Handrefraktometer, $\mathrm{pH}$ meter, kamera digital, roll meter, do meter, timbangan, current meter, fins dan masker, Arcgis 10.2, data sheet lapangan, kantong plastik, botol sampel (steril), cool box (berisi es batu), kertas label, alat tulis (spidol permanen, pensil, pena), air mineral, data pasang surut. Selain itu alat dan bahan laboratorium yang digunakan dalam menganalisis kualitas air (fisik, kimia, biologi dan logam 
terlarut) antara lain : tabung reaksi, kaca pengaduk, corong, labu ukur, kuvet, spektrofotometer, oven, erlenmeyer, beaker gelas, gelas ukur, gelas piala, pipet volume, penangas listrik, timbangan analitik, elenmeyer, serta bahanbahan kimia dan akuades.

\section{Teknik Pengumpulan Data}

Pada tahap ini dilakukan survey awal lokasi penelitian, serta pengumpulan data sekunder. Data sekunder seperti data arus dan pasang surut.

Metode penentuan stasiun pengamatan dilakukan dengan teknik purposive sampling, yaitu dengan mempertimbangkan kondisi dan keadaan daerah yang diduga berpengaruh terhadap kualitas perairan pantai. Pemilihan lokasi stasiun mempertimbangkan beberapa kriteria seperti: pantai memiliki kemiringan rendah hingga moderat (1545o), pantai tidak terhalang oleh jeti atau pemecah gelombang atau struktur bangunan lainnya. Lokasi penelitian dibagi dalam empat stasiun pengamatan yaitu stasiun 1 (dekat dermaga baru), stasiun 2 (berdekatan dengan lokasi wisata pemandian baru), stasiun 3 (depan Kan- tor Balai Budidaya Laut) dan stasiun 4 (dekat dengan Tanjung Manggewa).

Pengambilan limbah padat/sampah dilakukan dengan mengkombinasi teknik transek garis (Line Intersept Transect) dan transek sabuk (Belt Transect). Pengamatan limbah padat dibatasi pada sampah anorganik dan organik padat yang ditemukan di dalam kuadran transek. Sebanyak delapan line transek dipasang dengan pengaturan sebagai berikut : 4 plot dipasang sejajar sebelum batas garis pantai dan 4 plot sisanya dipasang sejajar setelah batas garis pantai. Panjang total line transek per 4 plot adalah 55 meter untuk satu stasiun pengamatan. Jarak antara masing-masing line plot transek dibuat 5 meter. Transek sabuk yang digunakan berbentuk kuadran dengan ukuran panjang 10 $\mathrm{m}$ dan lebar $5 \mathrm{~m}$ atau berukuran $50 \mathrm{~m} 2$ yang digunakan sebagai plot pengamatan untuk mengumpulkan sampel limbah padat. Pengamatan Limbah Padat pada Monsun Timur dilakukan sebanyak 2 kali yaitu pada saat air laut pasang dan pada saat air laut surut.

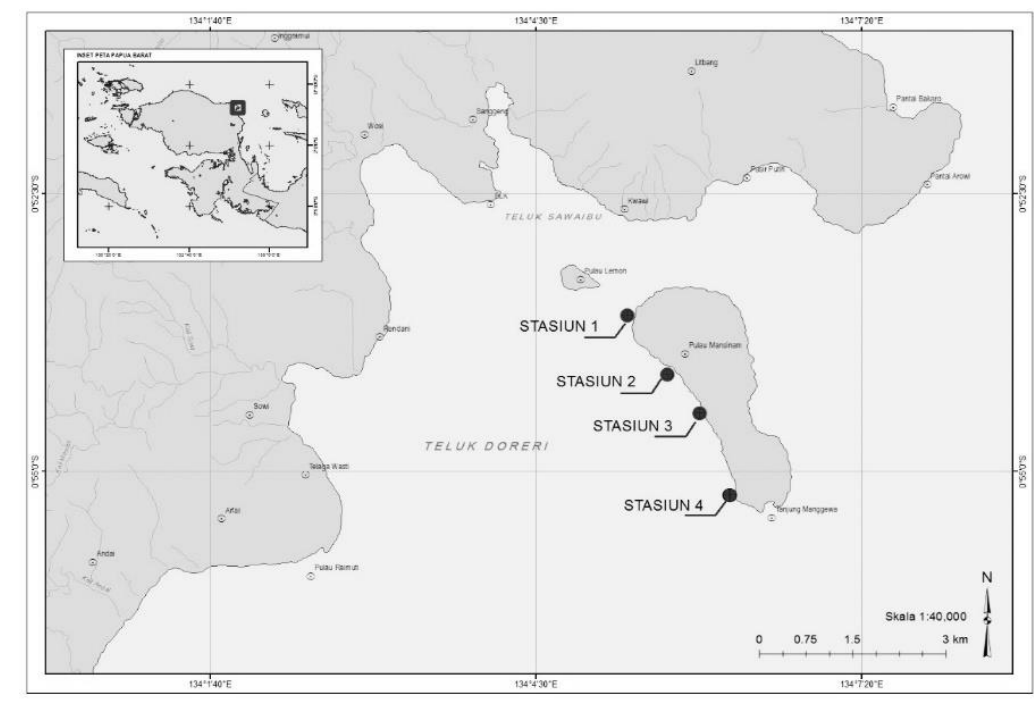

Gambar 1. Letak Stasiun Pengamatan di Pulau Mansinam (Skala 1:40.000) 
CASSOWARY volume I (1): 1 - 20

ISSN : 2614-8900

E-ISSN : 2622-6545

CProgram Pascasarjana Universitas Papua, https://pasca.unipa.ac.id/

Limbah padat yang dikumpulkan, dimasukkan ke dalam kantong plastik yang telah diberi label. Limbah padat selanjutnya dikeringkan dibawah matahari, dibersihkan dari pasir lalu disortir sesuai jenisnya. Limbah tersebut kemudian ditimbang untuk mengetahui berat keringnya. Pola penempatan transek kuadran disajikan pada Gambar 2.

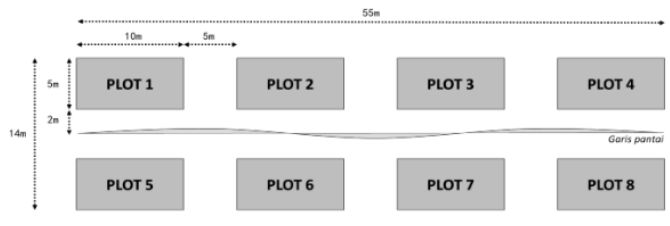

Gambar 2. Pola Penempatan Transek Kuadran

Untuk pengambilan data kualitas air pada keempat stasiun pengamatan di ambil 1x (untuk menjelaskan kualitas air pada Monsun Timur). Sampel air sebagian dianalisis di Laboratorium Kimia, Fakultas Matematika dan Ilmu Pengetahuan Alam, Universitas Papua.

\section{Variabel Pengamatan}

Variabel yang diamati dalam penelitian ini antara lain:

1. Parameter kualitas air yang meliputi:

a. Parameter fisika: warna, bau, kecerahan, kekeruhan, padatan tersuspensi (TSS), suhu, dan lapisan minyak.

b. Parameter kimia : $\mathrm{pH}$, salinitas, DO, BOD, amoniak, dan fosfat.

c. Parameter biologi : E. Coliform (Faecal), Coliform (Total).

d. Parameter logam terlarut : Cadmium dan Timbal

2. Nilai Indeks Pencemar dari parameter kualitas air.

3. Jenis, kepadatan, dan persentase limbah padat/sampah (berat kering) yang terdapat pada pesisir pantai baik limbah organik (antara lain; kayu, kertas, karton, dan makanan) maupun anorganik (antara lain; aluminium, kaca/gelas, plastik, logam, karet, kain, jala, tali, dan rokok).

\section{Analisis Data}

Kepadatan limbah padat berdasarkan beratnya dihitung dengan persamaan sebagai berikut :

$$
D_{i}=\frac{N_{i}}{A}
$$

Dimana:

Di = kepadatan limbah (i) per satuan luas $\left(\mathrm{gram} /{ }^{\mathrm{m} 2}\right)$

$\mathrm{Ni}=$ berat limbah (i)

$\mathrm{A}=$ luas daerah pengamatan $\left({ }^{\mathrm{m} 2}\right)$

Persentase relatif limbah padat berdasarkan berat limbah (i) dihitung dengan menggunakan persamaan berikut ini:

Dimana:

$$
R D_{i}=\frac{N_{i}}{\sum n_{y}} \times 100 \%
$$

$\mathrm{RDi}=$ persentase relatif limbah padat (i)

$\mathrm{Ni}=$ berat limbah (i) dalam transek kuadrans

$\sum \mathrm{n}_{\mathrm{y}}=$ jumlah atau total berat seluruh limbah

Penentuan status mutu air dilakukan dengan menggunakan metode Indeks Pencemaran menurut Kementerian Lingkungan Hidup (2003), sesuai dengan persamaan berikut:

$$
P I_{j}=\sqrt{\frac{\left(\frac{c_{i}}{l_{i j}}\right)_{M}^{2}+\left(\frac{c_{i}}{l_{i j}}\right)_{R}^{2}}{2}}
$$


Dimana:

$\begin{aligned} \mathrm{PIj} \quad & \text { indeks pencemaran bagi } \\ & \text { peruntukan (j) yang } \\ & \text { merupa-kan fungsi dari } \\ & \text { Ci/Lij } \\ \mathrm{Lij}= & \text { konsentrasi parameter } \\ & \text { kuali-tas air yang } \\ & \text { dicantumkan dalam baku } \\ & \text { mutu suatu perun-tukan } \\ & \text { air }(\mathrm{j}) \\ = & \text { menyatakan konsentrasi } \\ & \text { para-meter kualitas air (i) } \\ & \text { yang diperoleh dari } \\ & \text { analisis cupli-kan air pada } \\ & \text { suatu lokasi pengambilan } \\ & \text { cuplikan dari suatu alur } \\ & \text { sungai } \\ & \text { nilai, Ci/Lij maksimum }\end{aligned}$

Evaluasi terhadap nilai PI dapat dihubungkan langsung dengan kriteria sebagai berikut:

$$
\begin{aligned}
& 0 \leq \operatorname{PIj} \leq 1,0 \quad=\text { Memenuhi baku } \\
& 1,0<\operatorname{PIj} \leq 5,0=\text { Tercemar ringan } \\
& 5,0<\operatorname{PIj} \leq 10=\text { Tercemar sedang } \\
& \mathrm{PIj}>10=\text { Tercemar berat }
\end{aligned}
$$

\section{HASIL DAN PEMBAHASAN}

\section{Dinamika Perairan Teluk}

Arus sangat penting dalam sirkulasi air, pembawa bahan terlarut dan padatan tersuspensi (Dahuri, 2003). Arus laut dapat terjadi karena perbedaan salinitas massa air laut, tiupan angin pasang surut atau perbedaan permukaan dasar samudra.

Perubahan pola arus permukaan perairan laut yang terjadi karena adanya pengaruh angin musim yang terjadi setiap setengah tahun sekali berubah arah. Pada dasarnya arah arus laut searah dengan arah hembusan angin, tetapi bentuk permukaan pantai juga mempengaruhi arah arus laut. Arus pasang surut cukup dominan pada perairan teluk, sehingga mempengaruhi pola arus pasang surut air laut pada lokasi pengamatan pesisir pantai Pulau Mansinam.

Kecepatan arus perairan laut Pulau Mansinam pada stasiun I - IV berturut-turut adalah $0,16 \mathrm{~m} / \mathrm{s}, 0,04 \mathrm{~m} / \mathrm{s}$, $0,04 \mathrm{~m} / \mathrm{s}$, dan $0,13 \mathrm{~m} / \mathrm{s}$. Dari hasil tersebut didapatkan bahwa kecepatan arus perairan laut tinggi pada stasiun I dan stasiun IV dengan arah arus yang dominan yaitu dari barat dan masuk ke dalam teluk, dan rendah pada stasiun II dan stasiun III karena kondisi bentuk/kontur kedua stasiun yang berada pada cekungan dalam teluk sehingga arus yang masuk berputar melambat.

Pergerakan angin Monsun Timur berpengaruh pada pergerakan arus. Pola distribusi arus permukaan laut Pulau Mansinam dapat dilihat pada Gambar 4 dan Gambar 5. Apabila dilihat dari pola distribusi arus permukaan laut di Pulau Mansinam tersebut maka arah arus permukaan laut pada Monsun Timur (Juni-Agustus). Hal inilah yang menyebabkan arus permukaan air laut pada stasiun I dan stasiun IV lebih tinggi bila dibandingkan dengan stasiun II dan stasiun III. Dengan melihat pola arus yang demikian maka pada Munson Timur untuk peruntukan dalam wisata bahari (berenang dan snorkling) lebih baik dilakukan pada stasiun II dan III dimana kecepatan arus permukaan cukup rendah tetapi tidak pada stasiun I dan stasiun IV.

\section{Kualitas Perairan}

Pada empat stasiun penelitian dilakukan pengukuran terhadap kualitas perairan yang terdiri dari parameter fisika, kimia, biologi dan logam terlarut. Hasil analisis kualitas air menunjukan bahwa pada beberapa stasiun penelitian terdapat parameter yang telah melebihi ambang batas baku mutu yang diperuntukan untuk kegiatan wisata bahari yang 
mengacu pada Kepmen LH nomor 51 tahun 2004. Hasil analisis kualitas perairan di Pulau Mansinam dapat dilihat pada Tabel 6.

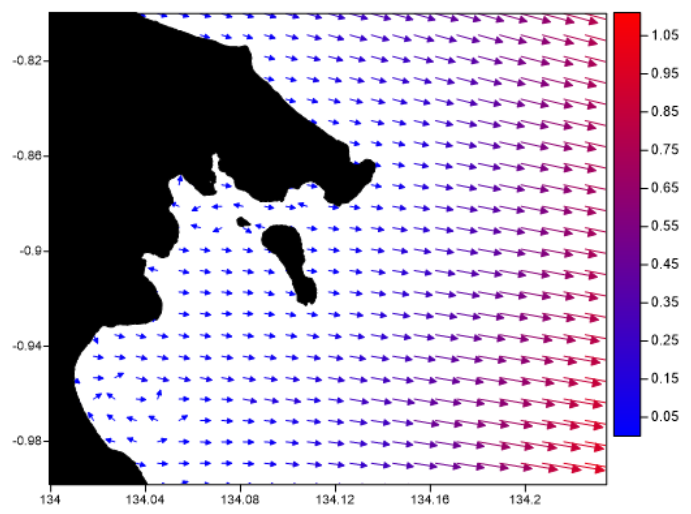

Gambar 3. Pola dan Kecepatan Arus Tahunan di Perairan Kota Manokwari

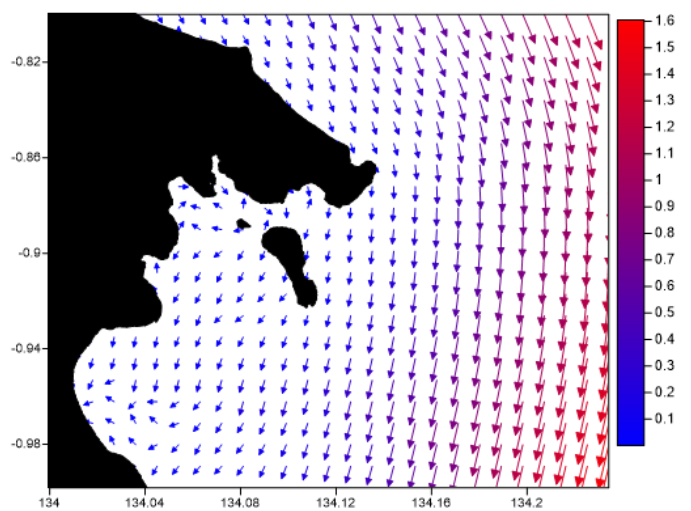

Gambar 4. Pola dan Kecepatan Arus pada Monsun Timur di Perairan Kota Manokwari.

\section{Kualitas Fisik Perairan Suhu}

Kondisi lingkungan perairan sangat dipengaruhi oleh faktor-faktor kimia dan fisik dari perairan tersebut, salah satu faktor fisik perairan adalah suhu. Suhu merupakan parameter oseanografi yang mempunyai pengaruh sangat dominan terhadap kehidupan biota perairan secara khusus ikan dan sumber daya hayati laut pada umumnya (Nontji, 1987; Effendi, 2003).

Organisme perairan seperti ikan maupun udang mampu hidup baik pada kisaran suhu $20^{\circ}-30^{\circ} \mathrm{C}$ (Trubus Edisi $425,2005)$. Suhu perairan di Indonesia pada kondisi Monsun Timur adalah $26^{\circ}$ $30^{\circ} \mathrm{C}$ (BMKG, 2013). Menurut Rasyid (2009), di perairan Indonesia, suhu maksimum terjadi pada:

- Musim Pancaroba I (musim peralihan I) yaitu pada bulan Maret - Mei,

- Musim Timur (Monsun Timur) yaitu pada bulan Juni - Agustus yang ditandai dengan curah hujan rendah dan kecepatan angin yang tinggi, dan

- Musim Pancaroba II (musim peralihan II) yaitu pada bulan September November.

Pada ketiga musim tersebut angin relative lemah sehingga proses pemanasan di permukaan terjadi terlalu kuat. Tingginya intensitas penyinaran dan dengan kondisi permukaan laut lebih tenang menyebabkan penyerapan panas kedalam air laut lebih tinggi sehingga suhu air menjadi maksimum. Dilain pihak, pada Musim Barat (Monsun Barat) yang terjadi pada bulan Desember - Februari, suhu mencapai minimum. Suhu perairan laut Pulau Mansinam pada ke empat stasiun pengamatan dalam penelitian ini berkisar antara $29,2^{\circ}$ $30,1^{\circ} \mathrm{C}$ atau rata-rata $29,7^{\circ} \mathrm{C}$.

Suhu perairan laut di ke empat stasiun pengamatan pada kondisi perairan yang dipengaruhi oleh Monsun Timur dimana kondisi arus permukaan perairan agak tenang sehingga menyebabkan penyerapan panas kedalam air laut lebih tinggi, sehingga suhu mencapai maksimum. Kondisi suhu perairan laut Pulau Mansinam pada stasiun I sampai dengan stasiun IV masih tergolong kondisi suhu yang baik atau dapat ditolerir oleh kehidupan organisme di perairan Pulau Mansinam. Suhu perairan $29,2^{\circ}-30,1^{\circ} \mathrm{C}$ pada perairan laut Pulau Mansinam masih tergolong alami dan memenuhi baku mutu untuk aktivitas wisata bahari. 


\section{Bau dan Warna}

Parameter fisik perairan, bau dan warna pada ke empat stasiun pengamatan tergolong tak berbau dan berwarna jernih. Warna air laut yang jernih mengindikasikan bahwa kondisi perairan laut Pulau Mansinam masih baik. Kondisi perairan laut yang tak berbau dan jernih memenuhi persyaratan baku mutu untuk kegiatan wisata bahari (permandian) (Kepmen. LH No. 51 Tahun 2004).

Kondisi perairan di Pulau Mansinam yang tak berbau dan berwarna jernih diduga karena meskipun aktivitas pembangunan di daratan dan sekitar pesisir laut Pulau Mansinam sedang berjalan, namun masih mampu di netralisir oleh pergerakan perairan teluk. Selain itu, dari hasil penelitian juga tidak ditemukan adanya limbah berwarna yang disebabkan oleh kegiatan industri yang merubah bau dan warna perairan laut Pulau Mansinam

\section{Kecerahan}

Parameter fisika yang erat kaitannya dengan proses fotosintesis pada suatu ekosistem perairan adalah kecerahan. Kecerahan merupakan ukuran transparansi perairan yang ditentukan secara visual dengan meng-gunakan sechi disk (Effendi, 2003). Kecerahan yang tinggi menunjukkan daya tembus cahaya matahari yang jatuh ke dalam perairan, begitu juga sebaliknya. Dengan kata lain kecerahan adalah suatu kondisi yang menunjukkan kemampuan cahaya untuk menembus lapisan air pada kedalaman tertentu.

Berdasarkan hasil penelitian di lapangan, kecerahan perairan laut Pulau Mansinam pada stasiun I sampai stasiun IV berkisar antara 12,3 $\mathrm{m}-14,0 \mathrm{~m}$ atau rata-rata $13,2 \mathrm{~m}$. Nilai kecerahan tertinggi didapatkan pada perairan laut di stasiun I $(14 \mathrm{~m})$ yang ditandai dengan perairannya yang masih terlihat sangat jernih. Rata-rata nilai kecerahan perairan laut Pulau Mansinam (13,2 m) ini dapat dikatakan relatif masih normal jika disesuaikan dengan peruntukkannya untuk wisata bahari.

Baku mutu parameter kecerahan yang ditetapkan untuk wisata bahari adalah > 6m (Kepmen. LH No. 51 Tahun 2004). Kondisi kecerahan $>6 \mathrm{~m}$ di nilai sangat baik untuk kemampuan mata/ jarak pandang mata di dalam perairan.

\section{Total Padatan Tersuspensi (TSS)}

Nilai padatan tersuspensi (TSS) perairan laut Pulau Mansinam, hasil pengamatan pada stasiun I sampai dengan stasiun IV berturut-turut adalah 56,67 mg/L, $196 \mathrm{mg} / \mathrm{L}, 116 \mathrm{mg} / \mathrm{L}$, dan 157,33 mg/L. Berdasarkan Kepmen. LH No. 51 Tahun 2004 tentang baku mutu air laut untuk wisata bahari adalah $\leq 80$ $\mathrm{mg} / \mathrm{L}$. Berdasarkan ketetapan tersebut maka hanya kandungan TSS perairan laut Pulau Mansinam pada stasiun I yang masih dalam kategori baik, sedangkan kandungan TSS perairan laut Pulau Mansinam pada stasiun II, III, dan IV sudah melampaui batas baku mutu.

Tarigan dan Edward (2003) menyatakan bahwa padatan tersuspensi (TSS) merupakan tempat berlangsungnya reaksi-reaksi kimia yang heterogen, dan berfungsi sebagai bahan pembentuk endapan yang paling awal dan dapat menghalangi kemampuan produksi zat organik di suatu perairan. Muatan TSS adalah lumpur, tanah liat, logam oksida, sulfida, ganggang, bakteri dan jamur.

Lokasi stasiun I, II, III merupakan lokasi yang mempunyai aktivitas di darat maupun di pesisir lebih tinggim di banding pada stasiun IV. Aktivitasaktivitas yang di duga sebagai penyebabnya adalah aktivitas pelabuhan baru, lokasi pemandian, aktivitas kantor Balai BudidayaLaut, dan aktivitas pondokpondok wisata. Aktivitas-aktivitas tersebut tentunya membawa pengaruh karena 
berkaitan dengan bongkar muat bahan baku bangunan dan cuci pakai peralatan yang digunakan oleh para tukang dipinggiran pesisir pada ketiga stasiun ini. Namun pada stasiun I nilai padatan tersuspensi (TSS) belum melampaui ambang batas baku mutu.

Tabel 1. Hasil Analisis Kualitas Perairan di Pulau Mansinam

\begin{tabular}{|c|c|c|c|c|c|c|c|c|}
\hline \multirow{2}{*}{\multicolumn{2}{|c|}{ Parameter }} & \multirow{3}{*}{$\begin{array}{c}\text { Satuan } \\
\left({ }^{\circ} \mathrm{C}\right)\end{array}$} & \multirow{3}{*}{$\begin{array}{l}\text { Baku } \\
\text { Mutu }\end{array}$} & \multicolumn{4}{|c|}{ Stasiun } & \multirow{3}{*}{$\begin{array}{c}\begin{array}{c}\text { Rata- } \\
\text { rata }\end{array} \\
29,70\end{array}$} \\
\hline & & & & 1 & 2 & 3 & 4 & \\
\hline \multirow{6}{*}{ Fisika } & Suhu & & & 29,6 & 29,2 & 29,9 & 30,1 & \\
\hline & Arus & $\mathrm{m} /$ detik & Alami & 0,16 & 0,04 & 0,11 & 0,13 & 0,11 \\
\hline & $\mathrm{Bau}$ & & $\mathrm{Tb}$ & $\mathrm{tb}$ & $\mathrm{Tb}$ & $\mathrm{tb}$ & $\mathrm{Tb}$ & $\mathrm{Tb}$ \\
\hline & Warna & & 30 & Jernih & Jernih & Jernih & Jernih & Jernih \\
\hline & Kecerahan & meter & $>6$ & 14 & 13 & 12,3 & 13,5 & 13,20 \\
\hline & $\begin{array}{l}\text { Padatan tersuspensi } \\
\text { (TSS) }\end{array}$ & $\mathrm{mg} / \mathrm{L}$ & 80 & 56,67 & $196^{*}$ & $116^{*}$ & $157,3^{*}$ & 131,50 \\
\hline \multirow{9}{*}{ Kimia } & $\mathrm{pH}$ & - & 7,75 & 8,25 & 8,16 & 8,21 & 8,1 & 8,18 \\
\hline & DO & $\mathrm{mg} / \mathrm{L}$ & 5,1 & 6,12 & 8,47 & 9,33 & 7,02 & 7,74 \\
\hline & BOD & $\mathrm{mg} / \mathrm{L}$ & 10 & 2,49 & 4,96 & 6,11 & 3,61 & 4,29 \\
\hline & $\begin{array}{l}\text { Amoniak Total } \\
\left(\mathrm{NH}_{3}-\mathrm{N}\right)\end{array}$ & $\mathrm{mg} / \mathrm{L}$ & 0,3 & 0,02 & 0,03 & 0,08 & 0,06 & 0,05 \\
\hline & Nitrat $\left(\mathrm{NO}_{3}-\mathrm{N}\right)$ & $\mathrm{mg} / \mathrm{L}$ & 0,008 & $0,016^{*}$ & $0,024 *$ & $0,043^{*}$ & $0,025^{*}$ & 0,027 \\
\hline & Fosfat $\left(\mathrm{PO}_{4}-\mathrm{P}\right)$ & $\mathrm{mg} / \mathrm{L}$ & 0,015 & $0,018^{*}$ & $0,017^{*}$ & $0,028^{*}$ & $0,022^{*}$ & 0,021 \\
\hline & Salinitas & $\%$ & Alami & 29 & 30 & 29 & 31 & 29,75 \\
\hline & Minyak dan Lemak & $\mathrm{mg} / \mathrm{L}$ & 5 & $6,8^{*}$ & $5,2 *$ & $7,2^{*}$ & $6,88^{*}$ & 6,52 \\
\hline & Surfaktan (MBAS) & $\mathrm{mg} / \mathrm{L}$ & 1 & 0,13 & 0,322 & 0,461 & 0,096 & 0,252 \\
\hline \multirow{3}{*}{$\begin{array}{l}\text { Logam } \\
\text { Terlarut }\end{array}$} & Timbal $(\mathrm{Pb})$ & $\mathrm{mg} / \mathrm{L}$ & 0,005 & ttd & Ttd & ttd & Ttd & Ttd \\
\hline & Cadmium (Cd) & $\mathrm{mg} / \mathrm{L}$ & 0,002 & $\mathrm{ttd}$ & Ttd & ttd & Ttd & Ttd \\
\hline & Tembaga $(\mathrm{Cu})$ & $\mathrm{mg} / \mathrm{L}$ & 0,05 & $0,0566^{*}$ & 0,0413 & 0,026 & 0,015 & 0,035 \\
\hline \multirow{2}{*}{ Biologi } & Total Coliform & MPN/ 100ml & 1000 & 920 & $>2400 *$ & $>2400^{*}$ & $>2400 *$ & $>2030$ \\
\hline & Faecal Coliform & MPN/ 100ml & 200 & 20 & $>2400 *$ & 7,8 & 11 & $>609$ \\
\hline
\end{tabular}

Keterangan:

tb : tidak berbau, ttd : tidak terdeteksi, Baku mutu mengacu pada Kepmen. LH No. 51 Tahun 2004 untuk wisata bahari, * nilai dari parameter kualitas perairan melebihi ambang batas baku mutu

Pada lokasi pengamatan I pergerakan arus lebih cepat karena berada di bagian ujung pulau, melalui pukulan ombak padatan tersuspensi terbawa arus dan terendap di stasiun pengamatan II.Selain itu padatan tersuspensi (TSS) tinggi pada stasiun II, III dan IV karena pengaruh putaran arus didalam teluk pada kondisi arus permukaan monsun timur ini, sehingga padatan tersuspensi yang bersumber dari aktivitas pembangunan Kota Manokwari terakumulasi dan tersuspensi pada stasiun II, III dan IV.

\section{Kualitas Kimia Perairan pH, DO dan BOD}

Kandungan oksigen terlarut merupakan banyaknya oksigen terlarut dalam suatu perairan. Berdasarkan hasil analisis laboratorium untuk ke empat stasiun pengamatan di Pulau Mansinam, didapatkan bahwa pH perairan laut Pulau Mansinam pada stasiun I adalah 8,25 , pada stasiun II 8,16, stasiun III 8,21 dan pada stasiun IV 8,10. pH suatu perairan mempunyai pengaruh yang besar terhadap organisme perairan sehingga seringkali dijadikan petunjuk untuk menyatakan baik buruknya suatu perairan (Odum, 1971). pH untuk wisata bahari ditetapkan antara $7-8,5$ (Kepmen.

LH No. 51 Tahun 2004). Berdasarkan ketetapan tersebut maka dapat dikatakan bahwa nilai $\mathrm{pH}$ perairan laut Pulau Mansinam pada stasiun I sampai dengan stasiun IV masih dalam batas baku mutu perairan laut untuk wisata bahari seperti permandian, snorkling, maupun diving.

Sanusi (2004) dalam Yazwar (2008) menyatakan bahwa nilai DO yang berkisar antara 5,45-7,00 mg/L cukup 
baik bagi proses kehidupan biota perairan. Berdasar Kepmen. LH No. 51

Tahun 2004, nilai DO untuk baku mutu perairan laut untuk wisata bahari adalah $>5 \mathrm{mg} / \mathrm{L}$. Nilai Oksigen Terlarut (DO) berdasarkan hasil analisis laboratorium untuk perairan laut Pulau Mansinam pada stasiun I sampai dengan stasiun IV berkisar antara $6,12 \mathrm{mg} / \mathrm{L}-$ $9,33 \mathrm{mg} / \mathrm{L}$. Nilai ini berarti masih memenuhi baku mutu nilai DO yang ditetapkan untuk kegiatan wisata bahari sebesar > 5mg/L. Nilai DO tertinggi didapatkan pada perairan laut di stasiun III (9,33 mg/L). Tingginya nilai DO pada perairan laut di stasiun III diduga karena di lokasi penelitian tersebut didapati adanya pertumbuhan lamun yang cukup banyak.

Nilai BOD perairan laut Pulau Mansinam pada stasiun I sampai dengan stasiun IV berturutturut adalah 2,49 $\mathrm{mg} / \mathrm{L}, 4,96 \mathrm{mg} / \mathrm{L}, 6,11 \mathrm{mg} / \mathrm{L}$ dan 3,61 $\mathrm{mg} / \mathrm{L}$. Prinsip pengukuran BOD pada dasarnya cukup sederhana, yaitu dengan mengukur kandungan oksigen terlarut awal (DO) dari sampel segera setelah pengambilan contoh, kemudian mengukur kandungan oksigen terlarut pada sampel yang telah diinkubasi selama 5 hari pada kondisi gelap dan pada suhu tetap $\left(20^{\circ} \mathrm{C}\right)$. Nilai BOD pada perairan laut di empat stasiun pengamatan di Pulau Mansinam masih di bawah nilai maksimum BOD yang ditetapkan oleh Kepmen. LH No. 51 Tahun 2004 sebesar $10 \mathrm{mg} / \mathrm{L}$. Oleh karena itu dapat dikatakan bahwa perairan laut di Pulau Mansinam masih aman untuk kegiatan wisata bahari.

\section{Nitrat, Fosfat dan Amoniak}

Kadar nitrat di perairan laut Pulau Mansinam pada ke empat stasiun pengamatan berkisar antara $0,016 \mathrm{mg} / \mathrm{L}$ - 0,043 mg/L. Kadar nitrat perairan laut Pulau Mansinam di ke empat stasiun pengamatan ini telah melampaui standar baku mutu perairan laut untuk wisata bahari yang ditetapkan sebesar 0,008 mg/L (Kepmen. LH No. 51 Tahun 2004). Effendi (2003) menyatakan bahwa nitrat merupakan bentuk utama nitrogen diperairan alami dan merupakan nutrien utama yang berguna bagi pertumbuhan tanaman dan alga, akan tetapi nitrat yang berlebih dalam suatu perairan dapat juga menjadi toksik (racun) bagi perairan. Nilai nitrat yang tinggi dapat dipengaruhi oleh adanya buangan limbah dari kegiatan budidaya BBL (Balai Budidaya Laut), karena adanya kegiatan pemberian pakan yang berlebihan yang mengakibatkan meningkatnya jumlah limbah organik, terutama yang mengandung unsur nitrogen dan fosfor. Sisa pakan dan metabolism dari aktivitas pemeliharaan ikan dapat menyebabkan eutrofikasi sehingga blooming fitoplankton pada perairan.

Hasil pengamatan menunjukkan, bahwa stasiun III memiliki kandungan nitrat yang cukup tinggi karena pada BBL (Balai Budidaya Laut) yang berada dekat stasiun tersebut hingga saat ini belum memiliki instalasi pengolahan air limbah budidaya ikan. Limbah tersebut langsung dibuang ke laut sekitarnya. Menurut Dinas Kelautan dan Perikanan Provinsi Papua Barat, instalasi pengolahan air limbah (IPAL) untuk kegiatan budidaya di Balai Budidaya Laut (BBL) Mansinam tersebut akan segera dibangun di tahun 2017.

Dengan adanya IPAL ini di harapkan limbah yang di buang ke perairan memenuhi baku mutu air limbah yang di syaratkan.

Kadar fosfat pada perairan laut Pulau Mansinam di empat stasiun pengamatan adalah sebagai berikut; pada stasiun I dengan nilai $0,018 \mathrm{mg} / \mathrm{L}$, pada stasiun II 0,017 $\mathrm{mg} / \mathrm{L}$, pada stasiun III $0,028 \mathrm{mg} / \mathrm{L}$, dan pada stasiun IV dengan nilai $0,022 \mathrm{mg} / \mathrm{L}$. Kadar fosfat yang didapatkan ini sudah melebihi baku mutu 
perairan laut untuk wisata bahari yang ditetapkan sebesar $0,015 \mathrm{mg} / \mathrm{L}$ (Kepmen. LH No 51 Tahun 2004). Ferianita, dkk (2005) mengemukakan bahwa fosfat dan nitrat merupakan zat hara yang paling penting bagi partumbuhan dan metabolisme fitoplankton dan merupakan indikator untuk mengevaluasi kualitas dan kesuburan perairan. Pada keempat stasiun pengamatan, stasiun III memiliki nilai fosfat yang tinggi karena limbah kotoran ikan dan sisa pakan ikan yang mengandung unsur hara fosfor dan nitrogen diperairan Pulau Mansinam cukup memadai. Limbah hasil aktivitas budidaya ikan dapat menyumbang ketersediaan nitrat dan fosfat yang menyuburkan perairan pantai Pulau Mansinam.

Amoniak total perairan laut Pulau Mansinam pada stasiun I sampai dengan stasiun IV berturut-turut adalah 0,02 mg/L, 0,03 mg/L, 0,08 mg/L, dan $0,06 \mathrm{mg} / \mathrm{L}$. Konsentrasi amoniak yang berlebih dapat menimbulkan permasalahan serius pada perairan. Menurut Sutomo (1989), bahwa amoniak dalam perairan laut budidaya dapat mengakibatkan kerusakan terhadap organisme, terutama kerusakan pada fungsi dan struktur organ.

Sesuai Keputusan Menteri Lingkungan Hidup No. 51 Tahun 2004, baku mutu Amoniak $\mathrm{NH}_{3}-\mathrm{N}$ perairan laut untuk wisata bahari adalah $0,30 \mathrm{mg} / \mathrm{L}$.

Kadar amonnia total di perairan laut Pulau Mansinam masih di bawah baku mutu yang ditetapkan, sehingga dapat dikatakan bahwa amoniak belum berlebih dalam perairan pulau mansinam pada keempat stasiun penelitian.

\section{Salinitas}

Hasil pengukuran salinitas perairan laut Pulau Mansinam pada stasiun I sampai dengan stasiun IV berkisar antara 29\%o - 31\%o. Menurut Nybakken (1992), kondisi salinitas air laut yang optimal untuk kelangsungan hidup suatu organisme adalah 30-35\%, sedangkan untuk daerah estuary berkisar antara 5-35\% dan untuk air tawar berkisar antara 0,55\%. Adapun kondisi salinitas perairan yang sesuai dengan baku mutu air laut untuk biota laut berdasarkan Kepmen. LH No. 51 Tahun 2004 adalah antara 2934\%o. Berdasarkan ini dapat dikatakan bahwa salinitas perairan laut Pulau Mansinam pada stasiun I sampai stasiun IV termasuk dalam kategori baik untuk pertumbuhan suatu organisme perairan laut.

\section{Minyak dan Lemak}

Kadar minyak dan lemak di perairan laut Pulau Mansinam pada ke empat stasiun pengamatan adalah sebagai berikut, yaitu pada stasiun I sebesar 6,80 mg/L, stasiun II 5,20 mg/L, stasiun III $7,20 \mathrm{mg} / \mathrm{L}$ dan stasiun IV sebesar $6,88 \mathrm{mg} / \mathrm{L}$. Nilai minyak dan lemak dari ke empat stasiun pengamatan ini melampaui batas baku mutu yang ditetapkan untuk perairan laut wisata bahari yang nilainya ditetapkan sebesar $5 \mathrm{mg} / \mathrm{L}$ (Kepmen. LH No. 51 Tahun 2004). Tingginya kadar minyak dan lemak pada perairan ini diduga bersumber dari aktivitas transportasi laut menyeberang ke Pulau Mansinam. Selain itu juga disebabkan oleh limbah dari masyarakat sendiri karena kondisi stasiun pengamatan yang berada dekat dengan pemukiman penduduk. Limbah minyak dan lemak baik yang berasal dari tingginya aktivitas perahu-perahu motor pada saat mengisi bahan bakar minyak yang biasa dilakukan di pesisir pantai maupun dari aktivitas pembersihan perahu motor oleh masyarakat setempat yang kemungkinan menyebar dari satu stasiun ke stasiun yang lain.

\section{Surfaktan}

Hasil pengamatan menunjukkan bahwa nilai surfaktan pada stasiun I - IV 
berkisar antara $0,130 \mathrm{mg} / \mathrm{L}-0,461$ $\mathrm{mg} / \mathrm{L}$. Surfaktan merupakan salah satu bahan pencemar di perairan yang diakibatkan dari aktivitas rumah tangga. Semakin tinggi aktivitas rumah tangga, semakin banyak buangan dari bahan ini yang masuk ke laut. Nilai surfaktan pada ke empat stasiun pengamatan di perairan laut Pulau Mansinam belum melewati ambang batas baku mutu yang diperuntukkan untuk wisata bahari yang ditetapkan sebesar $1 \mathrm{mg} / \mathrm{L}$ (Kepmen. LH No. 51 Tahun 2004). Oleh karena itu dapat dikatakan belum ada pengaruh yang signifikan dari kadar surfaktan yang ada di perairan laut Pulau Mansinam.

\section{Logam Terlarut \\ Timbal dan Cadmium}

Rukaesih (2004) mengemukakan bahwa Timbal $(\mathrm{Pb})$ yang berasal dari batuan kapur merupakan sumber timbal dari perairan alami.

Timbal $(\mathrm{Pb})$ dapat masuk ke perairan melalui pengkristalan di udara yang merupakan hasil pembakaran bahan bakar kendaraan bermotor dengan bantuan hujan. Selain itu bisa juga sebagai akibat proses korosifikasi bahan mineral akibat hempasan dan angin. Timbal $(\mathrm{Pb})$ yang masuk kedalam perairan laut dikarenakan antara lain; aktivitas industri, misal air buangan (limbah) industri yang jatuh pada jalurjalur perairan seperti anak sungai dan terbawa menuju laut.

Kadmium (Cd) dilain pihak dapat masuk kedalam perairan karena adanya proses erosi tanah dan/ atau pelapukan batuan induk. Selain itu, meningkatnya kadar kadmium (Cd) dalam air umumnya juga dikarenakan kegiatan perindustrian, dimana limbah hasil dari pabrik tersebut dibuang langsung kedalam perairan. Kepmen. LH No. 51. Tahun 2004 tentang baku mutu air laut untuk wisata bahari, kadar kadmium $(\mathrm{Cd})$ dan timbal $(\mathrm{Pb})$ masing-masing adalah sebesar 0,002 $\mathrm{mg} / \mathrm{L}$ dan 0,005 $\mathrm{mg} / \mathrm{L}$. Kadar $\mathrm{Cd}$ dan $\mathrm{Pb}$ di perairan laut Pulau Mansinam, hasil pengamatan pada stasiun I sampai dengan IV tidak terdeteksi (ttd). Tidak terdeteksinya kadar $\mathrm{Cd}$ dan $\mathrm{Pb}$ ini ada kemungkinan karena memang di sekitar Pulau Mansinam belum ada aktivitas industri sehingga perairan laut belum tercemar oleh limbah industri.

Meskipun aktivitas perahu motor akibat adanya wisata pemandian cukup tinggi, tetapi hasil pembakaran bahan bakar kendaraan bermotor diduga belum mengalami pengkristalan di udara yang menyebabkan terbentuknya limbah $\mathrm{Pb}$ (Rukaesih, 2004).

\section{Tembaga}

Salah satu logam berat yang bersifat toksik terhadap organisme air dan manusia pada batas konsentrasi tertentu adalah Tembaga $(\mathrm{Cu})$.

Menurut Palar (1994), aktivitas manusia seperti buangan industri, pertambangan $\mathrm{Cu}$, industry galangan kapal dan bermacam-macam aktivitas pelabuhan lainnya merupakan salah satu jalur yang mempercepat terjadinya peningkatan kelarutan $\mathrm{Cu}$ dalam badan-badan perairan.

Kadar tembaga $(\mathrm{Cu})$ pada perairan laut Pulau Mansinam di stasiun I adalah $0,0566 \mathrm{mg} / \mathrm{L}$, stasiun II 0,0413 $\mathrm{mg} / \mathrm{L}$, stasiun III $0,0260 \mathrm{mg} / \mathrm{L}$, dan pada stasiun IV 0,0153 mg/L. Kadar $\mathrm{Cu}$ di stasiun pengamatan melebihi baku mutu yang ditetapkan yaitu $0,05 \mathrm{mg} / \mathrm{L}$ (Kepmen. LH No 51 Tahun 2004). Tingginya kadar $\mathrm{Cu}$ pada perairan laut di stasiun I diduga karena stasiun I ini berdekatan dengan pelabuhan laut Pulau Mansinam yang baru. Sisa logam hasil pembangunan dan endapan-endapan logam dari aktivitas pelabuhan menjadi sumber yang di duga sebagai penyumbang logam berat ini. 


\section{Biologi}

\section{Total Coliform}

Parameter mikrobiologi total coliform dari sampel air ke empat stasiun pengamatan di perairan laut Pulau Mansinam adalah sebagai berikut: stasiun I sebesar 920 MPN/100ml, stasiun II, III, dan IV sama yaitu sebesar $>2400$ MPN/100ml.

Nilai total coliform yang didapatkan pada stasiun II, III dan IV melebihi batas baku mutu untuk wisata bahari yang ditetapkan sebesar 1000 MPN/100 ml. Tingginya nilai total coliform pada stasiun II dan III diduga karena banyak sekali aktivitas yang dilakukan oleh masyarakat di sekitar stasiun tersebut. Stasiun II dekat dengan pemukiman masyarakat, sedangkan stasiun III dekat dengan kantor Balai Budidaya Laut (BBL) Mansinam. Pada saat penelitian dilakukan, ditemukan banyak sekali sampah-sampah yang berasal dari sampah domestik masyarakat, juga sampah dari aktivitas wisata permandian. Ada dugaan, oleh karena putaran arus dalam teluk, sampahsampah dari Kota Manokwari terbawa ke perairan laut Pulau Mansinam. Sampahsampah ini kemungkinan besar adalah penyebab tingginya total coliform pada perairan laut Pulau Mansinam khususnya pada stasiun II dan III. Untuk stasiun IV yang lokasinya dekat dengan Tanjung Manggewa dengan tipe subtratnya pasir berlumpur dan banyak sekali lamun, terlihat perairannya sehat tetapi didapati pula sampah-sampah yang sama seperti stasiun II dan III yang diduga berasal dari aktivitas dalam teluk dari sampahsampah domestik Kota Manokwari yang terbawa arus.

\section{Feccal Coliform}

Fecal coliform pada perairan laut Pulau Mansinam di stasiun I adalah sebesar $20 \mathrm{MPN} / 100 \mathrm{ml}$, stasiun II > 2400 MPN/100ml, stasiun III 7,8 MPN/ 100ml, dan stasiun IV $11 \mathrm{MPN} / 100 \mathrm{ml}$. Fecal coliform perairan laut untuk wisata bahari adalah 200 MPN/100ml (Kepmen. LH No 51 Tahun 2004). Fecal coliform dan E. coli terindikasi kuat diakibatkan oleh pencemaran tinja, keduanya memiliki resiko lebih besar menjadi patogen di dalam air. Bakteri fecal coliform yang mencemari air memiliki risiko yang langsung dapat dirasakan oleh manusia yang mengkonsumsinya (Pracoyo, 2006). Pada stasiun II, nilai fecal coliformnya sangat tinggi yaitu >2400 MPN/100ml. Hal ini dikarenakan pada stasiun II aktivitas yang dilakukan oleh masyarakat sangat tinggi. Selain dekat dengan daerah wisata permandian, lokasi ini juga dekat dengan pemukiman penduduk dimana lokasi pembuangan kotoran (septi tank) berdekatan dengan pantai.

Pada stasiun II terdapat air payau/salobar yang biasa digunakan masyarakat untuk aktivitas mandidan mencuci. Sedangkan pada stasiun III dan stasiun IV lebih banyak dicemari oleh sampahsampah organik yang terbawa oleh arus. Fecal coliform umumnya bersumber dari hasil pencernaan. Di duga tingginya bakteri Fecal coliform ini di sebabkan oleh banyaknya hasil-hasil pencernaan yang terbuang ke perairan laut.

\section{Kualitas Perairan Laut Pulau Mansinam}

Berdasarkan Keputusan Menteri Lingkungan Hidup No. 51 Tahun 2004 tentang Baku Mutu Perairan Laut untuk Wisata Bahari maka didapatkan bahwa dari hasil analisis 19 parameter kualitas air perairan laut Pulau Mansinam pada empat stasiun pengamatan, 12 parameter (63\%) menunjukkan kondisi perairan masih dalam ambang batas yang diperkenankan, sedangkan 7 parameter sisanya ada beberapa yang melebihi ambang batas. 
Kondisi iklim sangat mempengaruhi kondisi kualitas perairan laut Pulau Mansinam. Pada kondisi angin Munson Timur arus didapatkan tinggi pada asiun I dan IV, dan rendah pada stasiun II dan III. Kecepatan arus yang rendah diduga ikut mempengaruhi tingginya beberapa parameter kualitas air seperti total coliform dan fecal coliform serta TSS. Kecepatan arus kemungkinan berpengaruh pada kadar nitrat, fosfat, dan minyak dan lemak. Hal ini nampak dari konsentrasi parameter tersebut yang lebih tinggi pada stasiun II dan III dimana kecepatan arusnya lebih rendah dari stasiun I dan IV.

\section{Indeks Pencemaran (IP)}

Nilai IP digunakan untuk mengetahui tingkat pencemaran suatu perairan berdasarkan baku mutu kualitas air yang ditetapkan.
Perhitungan indeks untuk indikator kualitas air laut yang diperuntukan sebagai kawasan wisata permandian dilakukan berdasarkan Keputusan Menteri Negara Lingkungan Hidup No. 51 Tahun

2004 Tentang Baku Mutu Air Laut untuk wisata bahari. Berdasarkan hasil olahan data untuk nilai Indeks Pencemaran didapatkan bahwa pada stasiun I, III dan IV perairan lautnya tercemar ringan, sedangkan perairan laut pada stasiun II telah tercemar sedang (Tabel 7). Nilai Indeks Pencemar pada stasiun I tertinggi pada nilai nitrat, dan minyak dan lemak. Stasiun II memiliki nilai IP tinggi pada parameter TSS, nitrat, dan faecal coliform. Stasiun III nilai IP tinggi untuk parameter nitrat dan total coliform, sedangkan stasiun IV nilai IP tinggi pada parameter TSS, nitrat dan total coliform.

Tabel 2. Indeks Pencemaran Parameter Kualitas Perairan Laut Pulau Mansinam pada Stasiun Pengamatan I, II, III, dan IV

\begin{tabular}{|c|c|c|c|c|}
\hline \multirow{2}{*}{ Parameter } & \multicolumn{4}{|c|}{$\mathbf{C}_{\mathrm{i}} / \mathbf{L}_{\mathrm{ij}}$} \\
\hline & S1 & S2 & S3 & S4 \\
\hline Kecerahan & $2,295^{*}$ & 2,131 & 2,016 & 2,213 \\
\hline Padatan Tersuspensi (TSS) & 0.70837 & 2.45 & 1.45 & 1.96662 \\
\hline $\mathrm{pH}$ & 1.06451 & 1.05290 & 1.05935 & 1.04516 \\
\hline DO & 1.2 & 1.66078 & 1.82941 & 1.37647 \\
\hline BOD & 0.249 & 0.496 & 0.611 & 0.361 \\
\hline Ammoniak Total & 0.066667 & 0.1 & 0.26666 & 0.2 \\
\hline Nitrat & $2 * *$ & $3 * *$ & $5.375^{*}$ & $3.125^{*}$ \\
\hline Fosfat & 1.2 & 1.13333 & 1.86666 & 1.46666 \\
\hline Minyak \& Lemak & 1.36 & 1.04 & 1.44 & 1.376 \\
\hline Surfaktan & 0.13 & 0.322 & 0.461 & 0.096 \\
\hline Tembaga & 1.132 & 0.826 & 0.52 & 0.306 \\
\hline Total Coliform & 0.92 & 2.4 & $2.4^{* *}$ & $2.4^{* *}$ \\
\hline Faecal Coliform & 0.1 & $12 *$ & 0.039 & 0.055 \\
\hline $\mathrm{Ci} / \mathrm{Lij} \mathrm{R}$ & 0,956 & 2,201 & 1,487 & 1,230 \\
\hline Pij & 1,758 & 8,627 & 3,944 & 2,375 \\
\hline Kategori & tercemar ringan & tercemar sedang & tercemar ringan & tercemar ringan \\
\hline
\end{tabular}

Keterangan:

(*) nilai maksimum dari $\mathrm{Ci} / \mathrm{Lij} \mathrm{M},(* *)$ nilai $\mathrm{Ci} / \mathrm{Lij}$ tertinggi kedua dari beberapa parameter kualitas air 
CASSOWARY volume I (1): 1 - 20

ISSN : 2614-8900

E-ISSN : 2622-6545

CProgram Pascasarjana Universitas Papua, https://pasca.unipa.ac.id/

Tingginya nitrat di perairan dikarenakan adanya buangan limbah dari Balai Budidaya Laut Mansinam dan Pelabuhan Laut Manokwari serta hamparan lamun pada stasiun III dan IV. Arus permukaan pada Monsun Timur yang bergerak dari arah Barat mengakibatkan konsentrasi nitrat menjadi lebih tinggi pada stasiun II, III dan IV dibanding stasiun I. Adanya pembukaan lahan dengan peruntukannya untuk pembangunan seperti antara lain; perumahan, perkantoran, jalan, puskesmas, dan sekolah di Pulau Mansinam menyebabkan tingginya aktivitas bongkar muat kapal yang dapat memberikan sumbangsih pencemar berupa tumpahan minyak dan lemak dilaut. Sampah-sampah lokal dari sisa aktivitas wisata dan juga sampah kiriman dari Kota Manokwari yang terbawa arus hingga terdampar dan mengotori Pulau Mansinam menyebabkan tingginya fecal coliform dan total coliform di perairan, selain disebabkan juga oleh saluran pembuangan kotoran (septitank) dari perumahan yang berlokasi dekat dengan pesisir laut Pulau Mansinam.

Berdasarkan nilai Indeks Pencemaran tersebut, maka perairan pesisir laut Pulau Mansinam pada saat Muson Timur masih memenuhi persyaratan untuk wisata bahari pada saat pasang, sedangkan pada saat surut pada lokasi pengamatan II tidak di syaratkan.

\section{Sanitasi Lingkungan}

Sanitasi lingkungan pesisir adalah merupakan upaya pengendalian pesisir pantai untuk memelihara dan melindungi kebersihan pantai terhadap aktivitas fisik dari manusia (Azwar, 1990). Kebersihan pesisir pantai di Pulau

Mansinam sangat dipengaruhi oleh aktivitas yang ada di sekitarnya baik aktivitas di laut maupun di darat. Aktivitas penduduk di wilayah pesisir seperti pelayaran, rekreasi, perhotelan, pertanian, perdagangan, dan pemukiman dapat menimbulkan penurunan kualitas perairan. Pulau Mansinam merupakan pulau yang memiliki jarak dekat dengan daratan utama Kota Manokwari dan berada di dalam Teluk Doreri, sehingga diduga Pulau Mansinam sudah banyak mendapat pengaruh dari aktivitas manusia berupa buangan limbah pencemar.

Adanya pertambahan penduduk di Kota Manokwari, yang mengakibatkan daerah pesisir menerima dampak yang cukup besar dengan masuknya berbagai bahan pencemar atau sampah dengan jenis dan volume yang terus meningkat dari tahun ke tahun. Pada lokasi pengamatan stasiun I - IV ratarata ditemukan adanya sampah di pesisir, selain juga ada jamban dari beberapa rumah masyarakat ada yang letaknya dekat dengan pantai.

Tidak adanya instalasi pembuangan limbah pada Balai Budidaya Laut juga mempengaruhi sanitasi perairan Pulau Mansinam karena letaknya yang dekat dengan pantai dan buangan limbahnya langsung ke laut.

\section{Jenis Sampah Padat}

Jenis sampah padat yang ada di pesisir Pulau Mansinam pada empat stasiun pengamatan ditampilkan pada Tabel 8. Hasil penelitian dari ke empat stasiun pengamatan di pesisir Pulau Mansinam menunjukkan bahwa ada sembilan (9) jenis sampah padat yang terbagi kedalam dua kategori sampah yaitu sampah organik dan sampah anorganik.

Jenis sampah organik yang ditemukan terdiri dari: dedaunan, batang kayu, dan buah kelapa, sedangkan jenis sampah anorganik terdiri dari antara lain: aluminium, kaca, plastik, logam, kain, stereoform, keramik dan pampers. Berdasarkan kondisi pasang dan surut ada 
perbedaan jenis sampah yang ditemukan. Pada kondisi surut jenis sampah yang ditemukan sebanyak 6 - 9 jenis lebih banyak daripada kondisi pasang yang hanya $5-6$ jenis. Pada kondisi pasang tidak ditemukan sampah dari jenis logam kain, jala, dan keramik, sedangkan pada kondisi surut jenis sampah yang diketemukan pada semua stasiun ada 6 jenis yaitu aluminium, kaca, plastik, kain, pampers, dan dedaunan/batang/buah. Sampah anorganik dari jenis alumunium, plastik, pampers, dan sampah organik (daun/ batang/buah) diketemukan di semua stasiun pengamatan baik pada kondisi pasang maupun surut. Pada kondisi surut, jenis sampah yang terbanyak didapatkan pada stasiun I (9 jenis).

Tabel 3. Jenis-jenis sampah padat yang ditemukan pada pesisir pulau mansinam pada stasiun pengamatan $\mathrm{i}$, ii, iii, dan iv saat kondisi pasang dan surut

\begin{tabular}{|c|c|c|c|c|c|c|c|c|}
\hline \multirow{2}{*}{ Jenis Sampah } & \multicolumn{4}{|c|}{ Kondisi Pasang } & \multicolumn{4}{|c|}{ Kondisi Surut } \\
\hline & ST 1 & ST 2 & ST 3 & ST 4 & ST 1 & ST 2 & ST 3 & ST 4 \\
\hline Aluminium & $\sqrt{ }$ & $\sqrt{ }$ & $\sqrt{ }$ & $\sqrt{ }$ & $\sqrt{ }$ & $\sqrt{ }$ & $\sqrt{ }$ & $\sqrt{ }$ \\
\hline Kaca & & & & $\sqrt{ }$ & $\sqrt{ }$ & $\sqrt{ }$ & $\sqrt{ }$ & $\sqrt{ }$ \\
\hline Plastik & $\sqrt{ }$ & $\sqrt{ }$ & $\sqrt{ }$ & $\sqrt{ }$ & $\sqrt{ }$ & $\sqrt{ }$ & $\sqrt{ }$ & $\sqrt{ }$ \\
\hline Logam & & & & & $\sqrt{ }$ & & & \\
\hline Kain & & & & & $\sqrt{ }$ & $\sqrt{ }$ & $\sqrt{ }$ & $\sqrt{ }$ \\
\hline Jala & & & & & & & $\sqrt{ }$ & \\
\hline Stereoform & $\sqrt{ }$ & $\sqrt{ }$ & $\sqrt{ }$ & $\sqrt{ }$ & $\sqrt{ }$ & & & \\
\hline Keramik & & & & & $\sqrt{ }$ & & & $\sqrt{ }$ \\
\hline Pampers & $\sqrt{ }$ & $\sqrt{ }$ & $\sqrt{ }$ & $\sqrt{ }$ & $\sqrt{ }$ & $\sqrt{ }$ & $\sqrt{ }$ & $\sqrt{ }$ \\
\hline Daun/batang/buah & $\sqrt{ }$ & $\sqrt{ }$ & $\sqrt{ }$ & $\sqrt{ }$ & $\sqrt{ }$ & $\sqrt{ }$ & $\sqrt{ }$ & $\sqrt{ }$ \\
\hline Total Jenis & 5 & 5 & 5 & 6 & 9 & 6 & 7 & 7 \\
\hline
\end{tabular}

Keterangan: $(\sqrt{ })$ : mengartikan ada ditemukan jenis sampah tersebut, ST : stasiun

\section{Kepadatan Sampah}

Hasil penelitian menunjukkan bahwa baik sampah anorganik dan organik lebih dominan ditemukan pada perairan laut saat kondisi surut dibandingkan pada kondisi pasang. Pada saat perairan laut surut, total kepadatan sampah anorganik rata-rata dari ke empat stasiun pengamatan mencapai 3,81 gram/ ${ }^{\mathrm{m} 2}$, sedangkan pada saat pasang kepadatan sampah anorganik hanya 2,56 gram $/ \mathrm{m}^{2}$. Pada kondisi perairan laut surut kepadatan sampah organik mencapai $6,03 \mathrm{gram} / \mathrm{m}^{2}$, sedangkan pada kondisi pasang mencapai 23,29 gram $/ \mathrm{m}^{2}$ (lihat Gambar 5 dan 6).

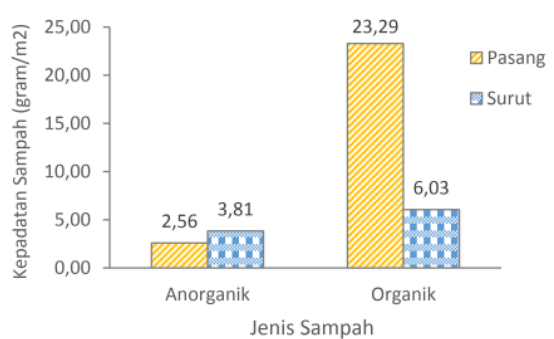

Gambar 5. Kepadatan Sampah Anorganik dan Organik Pada Seluruh Stasiun Pengamatan Saat Kondisi Pasang dan Surut

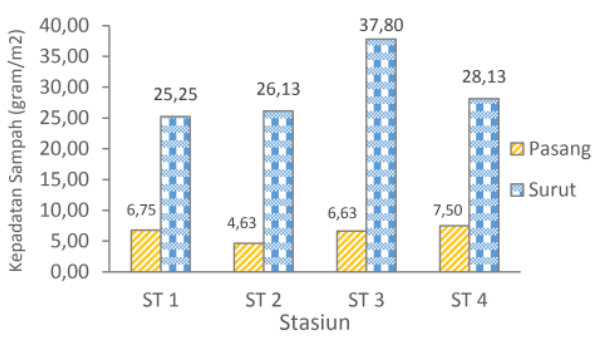

Gambar 6. Total Kepadatan Sampah untuk Tiap Stasiun Penelitian pada Kondisi Pasang dan Surut 
Disamping itu, hasil penelitian menunjukan bahwa kepadatan sampah berdasarkan beratnya tertinggi pada stasiun IV dengan total $7,50 \mathrm{gram} / \mathrm{m}^{2}$ pada kondisi pasang. Sementara itu untuk stasiun I dan stasiun III total berat sampah tidak berbeda jauh yaitu 6,75 gram $/ \mathrm{m}^{2}$ dan 6,63 gram $/ \mathrm{m}^{2}$. Sedangkan untuk stasiun II berat total hasil pengukuran yaitu yang terendah sekitar $4,63 \mathrm{gram} / \mathrm{m}^{2}$. Total berat dari sampah jika dijumlahkan untuk seluruh stasiun lebih banyak ditemukan padackondisi surut dibandingkan kondisi pasang. Pada kondisi surut stasiun III memiliki kepadatancsampah tertinggi disbandingkan stasiun lain yaitucsekitar 37,80 $\mathrm{gram} / \mathrm{m}^{2}$, sedangkan stasiun 1cterendah yaitu $25,25 \mathrm{gram} / \mathrm{m}^{2}$.

\section{Komposisi Jenis Sampah}

Persentase komposisi jenis sampah di pesisir pantai Pulau Mansinam berdasarkan jenisnya saat kondisi pasang dan surut disajikan pada Gambar 7. Berdasarkan diagram pie Nampak bahwa tiga komposisi sampah terbanyak di pesisir pantai Pulau Mansinam baik saat kondisi pasang maupun surut adalah sampah organik (dedaunan, batang kayu, dan buah), plastik, dan pampers.

Pada saat kondisi surut, komposisi sampah plastik yang ada di pesisir pantai Pulau Mansinam menduduki peringkat pertama terbanyak di semua stasiun dengan rincian pada stasiun I sebesar 57\%, stasiun II sebesar 36\%, stasiun III sebesar 35\%, dan stasiun IV sebesar $51 \%$. Pada saat kondisi pasang, persentase sampah plastic menurun, yaitu pada stasiun I turun menjadi $20 \%$, stasiun II $14 \%$, stasiun III $11 \%$ dan stasiun IV Pada saat pasang12\%. Turun- nya persentase sampah plastik saat kondisi pasang diduga karena arus air laut saat pasang membawa sampah plastik ini ke bagian yang lain dari Pulau Mansinam atau kemungkinan sampah plastik tersebut sudah terendap di lautan. Saat kondisi surut, persentase sampah terbanyak kedua tidak sama untuk setiap stasiun.

Pada stasiun I dan II persentase sampah terbesar kedua adalah pampers, masing-masing $21 \%$ dan $33 \%$, tetapi pada stasiun III dan IV persentase sampah terbesar kedua adalah sampah organic (dedaunan/batang kayu, dan buah) masing-masing sebesar $21 \%$ dan $32 \%$.

Berbeda dengan saat kondisi surut, saat kondisi pasang persentase sampah yang terbanyak adalah sampah organik yang ditemukan di semua stasiun pengamatan dengan rincian sebagai berikut: pada stasiun I sebesar $41 \%$, stasin II sebesar $62 \%$, stasiun III sebesar $64 \%$, dan stasiun IV sebesar $72 \%$. Tingginya persentase sampah organik seperti daun/batang/buah di semua stasiun pengamatan ini, diduga dikarenakan adanya aktivitas masyarakat seperti pembukaan lahan untuk pembangunan di pesisir Pulau Mansinam dan sekitar pesisir Kota Manokwari, yang terbawa oleh arus ke pesisir Pulau Mansinam tersebut. Meningkatnya kepadatan sampah di pulau Mansinam, diduga dikarenakan seiring dengan bertambahnya jumlah penduduk dan pendapatan masyarakat di pulau mansinam maupun di kota manokwari. Juga volume sampah yang tinggi berkaitan dengan kurangnya tingkat kesadaran masyarakat dalam mengelola limbah rumah tangga. 

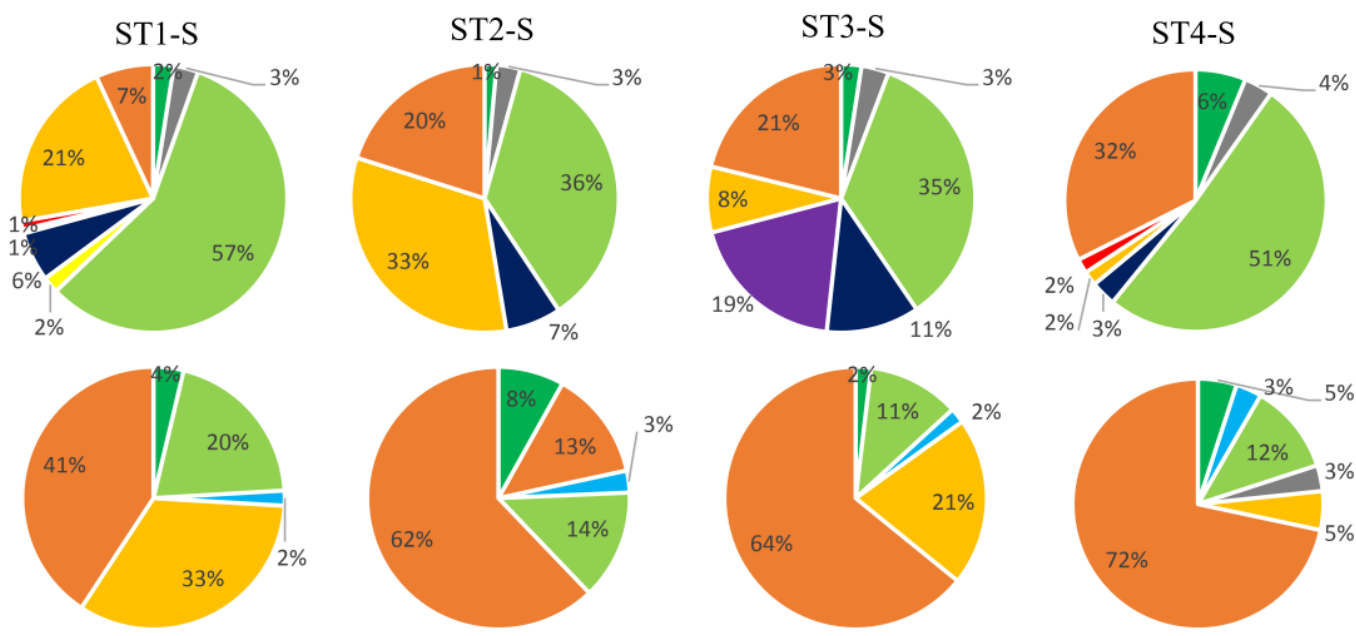

ST1-P

ST2-P

ST3-P

ST4-P

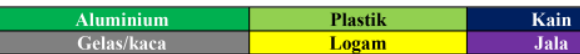

Kain

Gambar 7. Persentase Komposisi Sampah Padat di Pesisir Laut Pulau Mansinam pada Stasiun Pengamatan I, II, III, dan IV Saat Kondisi Surut dan Pasang

Komposisi sampah berbeda saat kondisi surut dan pasang dikarenakan musim di Indonesia berada dalam pengaruh angin muson, dimana angina sangat menentukan terjadinya gelombang dan arus di permukaan laut. Selain itu persentase sampah pada kondisi surut tinggi karena adanya penyebaran sampah dari pengaruh putaran arus permukaan di dalam teluk yang membawa sampah dari kota manokwari ke pulau mansinam, juga dari adanya aktivitas manusia yang banyak berkunjung untuk berlibur di pesisir pantai pulau mansinam saat kondisi surut (pagisore hari). Sehingga dari aktivitas tersebut banyak ditemukan sampahsampah yang dibuang secara tidak bertanggung jawab, seperti sampah botol minuman, bungkus makanan, dan lain sebagainya. Adanya sampah pemukiman masyarakat pulau mansinam dapat berakhir juga di lingkungan laut jika di buang secara sembarangan, seperti sampah plastik dan pampers yang paling dominan ditemukan di lokasi penelitian.

\section{KESIMPULAN DAN SARAN}

\section{Kesmipulan}

Berdasarkan hasil pengamatan dan analisis data yang telah dilakukan dapat disimpulkan beberapa hal sebagai berikut:

1. Kualitas fisik, biologi, kimia dan logam terlarut perairan laut Pulau Mansinam pada Monsun Timur dari 19 parameter yang diamati 12 parameter $(63 \%)$ berada dalam batas ambang baku mutu dan 7 parameter (37\%) telah berada di atas ambang batas baku mutu untuk wisata bahari.

2. Pola distribusi arus permukaan laut di Pulau Mansinam pada Monsun Timur (JuniAgustus) dominan mengarah dari arah barat dan masuk ke dalam teluk.

3. Tingkat pencemaran berdasarkan Indeks Pencemaran perairan laut Pulau Mansinam tergolong tercemar ringan untuk tujuan wisata bahari.

4. Jenis sampah an-organik memiliki komposisi tertinggi baik pada kondisi surut maupun pasang. Sampah plastik menduduki peringkat terbanyak pertama saat kondisi surut, sedangkan 
sampah organik menduduki peringkat terbanyak pertama saat kondisi pasang.

5. Komposisi jenis sampah di jumpai berbeda pada kondisi surut dan pasang dikarenakan musim di indonesia berada dalam pengaruh angin muson, dimana angin sangat menentukan terjadinya gelombang dan arus permukaan perairan laut teluk

\section{Saran}

1. Hasil pengamatan menunjukkan bahwa Diharapkan kepada pemerintah dan para pemangku kepentingan atau stakeholder dan semua lapisan masyarakat yang ada di Kabupaten Manokwari untuk bekerja sama menjaga kebersihan pantai di Pulau Mansinam.

2. Perlu dilakukan kajian lebih lanjut terkait kondisi kesehatan perairan Teluk Doreri khususnya Pulau Mansinam yang merupakan wisata religi dan wisata bahari (permandian, snorkling, diving)

3. Perlu digalakkan lagi kegiatankegiatan yang dapat menumbuhkan rasa memiliki terhadap pesisir laut supaya dapat dijaga keindahannya oleh pemerintah daerah melalui dinas-dinas terkait, dengan melibatkan masyarakat setempat.

4. Diharapkan kepada dinas terkait (Dinas Kelautan dan Perikanan Provinsi Papua Barat) agar dapat merealisasikan pembuatan Instalasi Pengolahan Limbah (IPAL) budidaya pada kantor Balai Budidaya Laut (BBL) Mansinam.

\section{DAFTAR PUSTAKA}

Hasil pengamatan menunjukkan bahwa BMKG. 2013. Rapat Pembahasan prakiraan musim hujan 2013/2014 dengan instansi terkait. Bahan presentasi BMKG tentang prakiraan cuaca Jakarta.. BMKG Jakarta.

Dahuri, H.R., J. Rais, S.P. Ginting dan H.J. Sitepu, 1996. Pengelolaan Wilayah Pesisir dan Laut Secara Terpadu. Jakarta. Pradnya Paramita

Dahuri, R. 2003. Keanekaragaman Hayati Laut Aset Pembangunan Berkelanjutan Indonesia. PT Gramedia Pustaka Utama. Jakarta

Duxbury, A. B and A.C. Duxbury, 1993. Fundamental of Oceanography. Wm. C. Brown Publ. Washington

Effendi H. 2003. Telaah Kualitas Air bagi Pengelolaan Sumber Daya dan

Lingkungan Perairan. Kanisius. Yogyakarta

Elyazar N, Mahendra MS, dan Wardi IN. 2007.

Dampak Aktivitas Masyarakat Terhadap Tingkat Pencemaran Air Laut di Pantai Kuta Kabupaten Badung Serta Upaya Pelestarian Lingkungan. Ecotropic, 2(1): 1- 18

Ferianita, F.M, Herman H, dan L.C. Sitepu. 2005. Komunitas Fitoplankton Sebagai BioIndikator Kualitas Perairan Teluk Jakarta.

Seminar Nasional MIPA 2005. FMIPA Universitas Indonesia, $24-26$ November 2005. Jakarta.

Imagea. 2011. Stratifikasi Suhu. http://googleimage.com (diakses pada 29 Mei 2016)

Kepmen. LH No. 51 Tahun 2004 Tentang Baku Mutu Air Laut : http://garasibiologi.blogspot.co.i d/2013/05/baku-mutu-airlaut. html\#sthash.JjrerpJl.dpuf [diaskes pada 31 Maret 2016].

Nontji, A. 1993. Laut Nusantara. Penerbit Djambatan. Jakarta

Nybakken, J .W. 1992. Biologi Laut: 
Suatu Pendekatan Ekologis. Alih BahasaH.M. Eidman, Koesoebiono, D. G. Bengon. M. Hutomo dan S. Sukardjo. PT. Gramedia. Jakarta.

Odum, E.P. 1971. Fundamental of Ecology. U.S.A: W.B. Saunders Company.

OSCAR-NOAA. 2014. Rerata Tahunan (2014) Arah dan Kecepatan Arus (m/s) Di Perairan Kota Manokwari. ODV dan SURFER (OSCAR NOAA).

Patahuddin R. 2010. Keanekaragaman Makrozoobentos Pada Ekosistem Terumbu Karang Pulau Mansinam dan Pulau Lemon. Skripsi. FPPK UNIPA.

Palar, H. 1994. Pencemaran dan Toksikologi Logam Berat. Rineka Cipta. Jakarta Pracoyo, N.E. 2006, Penelitian Bakteriologik Air

Minum Isi Ulang di Daerah Jabodetabek Tahun 2004, Pusat Pemberantasan Penyakit, Departemen Kesehatan Republik Indonesia, Jakarta.

Rasyid. 2009. Distribusi klorofil a Pada Musim Peralihan Barat-Timur Di Perairan Spermonde Propinsi Sulawesi Selatan. Jurnal Sains \& Teknologi Vol 9 No 2 : 125-132 Universitas Hassanudin. Makasar

Rukaesih, A. 2004. Kimia Lingkungan. ANDI Yogyakarta. Jakarta

Sutomo AB, Riyono SH, dan Santoso. 1989.

Kandungan klorofil fitoplankton di Ujung Watu, Jepara, Jawa Tengah Dalam; Penelitian Oseanologi Perairan

Indonesia, Buku I (Biologi, Geologi, Lingkungan dan Oseanografi). P3O- LIPI. Jakarta.

Tarigan, M.S dan Edward. 2003. Kandungan Total Zat Padat
Tersuspensi (Total Suspended Solid) di Perairan Raha Sulawesi Tenggara. Jurnal. Bidang Dinamika Laut, Pusat Penelitian Oseanografi, Lembaga Ilmu Penge-tahuan Indonesia. Jakarta.

Trubus. "Pembudidayaan Artemia Untuk Pakan Udang \& Ikan". Trubus Edisi 425, April, 2005, h. 207.

Yazwar. 2008. Kelimpahan Plankton dan kaitannya dengan kualitas air di prapatan danau toba. Tesis. USU : Medan 